\title{
Status, threats and conservation strategies for orchids of western Himalaya, India
}

\author{
Jeewan Singh Jalal \\ Botanical Survey of India, Western Regional Centre, 7 Koregaon Road, Pune, Maharashtra 411001, India \\ Email: jeewansinghjalal@rediffmail.com
}

\begin{abstract}
The present study is an attempt to give an account of the current status of orchids based on recent surveys since 2002 to 2010 in various parts of western Himalaya. Based on rarity Index of species, orchids are categorised in four groups,very rare, sparse, occasional and common. Results show that $40 \%$ of orchid species are very rare, $26 \%$ are sparse, $19 \%$ are occasional and $15 \%$ are common in western Himalaya. For the conservation of orchids, two orchid conservation areas are identified in Gori Valley and Mandal Valley.
\end{abstract}

Keywords: Conservation, Gori Valley, Mandal Valley, orchids, Western Himalaya.

The International Union for Conservation of Nature (IUCN) has played a major role in focusing global concern on the loss or extinction of species and is now the accepted authority on such matters. The first Red Data Book was launched by IUCN in 1966. Now, it is revised annually and called the IUCN Red List, which is available in its electronic version since 2000. Threats to orchid species in the Indian region were first documented by Pradhan (1971, 1975a,b) and Pradhan (1975). Pradhan (1978) contributed the first red data

Date of publication (online): 26 December 2012

Date of publication (print): 26 December 2012

ISSN 0974-7907 (online) | 0974-7893 (print)

Editor: Pankaj Kumar

Manuscript details:

Ms \# 03062

Received 09 January 2012

Final received 08 August 2012

Finally accepted 29 October 2012

Citation: Jalal, J.S. (2012). Status, threats and conservation strategies for orchids of western Himalaya, India. Journal of Threatened Taxa 4(15): 3401-3409.

Copyright: (c) Jeewan Singh Jalal 2012. Creative Commons Attribution 3.0 Unported License. JoTT allows unrestricted use of this article in any medium for non-profit purposes, reproduction and distribution by providing adequate credit to the authors and the source of publication.

Acknowledgements: The author is thankful to Dr. Paramjith Singh, Director, Botanical Survey of India for encouragement and facilities. Thanks to Ministry of Environment and Forests, Government of India and Department of Science and Technology, Government of India for financial support to carry out this work.

\section{OPEN ACCESS I FREE DOWNLOAD (C) (i) ()}

sheet on Indian orchids to the IUCN Plant Red Data Book, which served as a model for the production of Red Data Book of Indian Plants. Nayar \& Sastry (1987, 1988, 1990), listed 58 species threatened in India. It also included 13 orchid species of western Himalaya. In 1984, under the banner of IUCN, the Orchid Specialist Group (OSG) was established for orchid conservation. It has many regional groups; ISROSG-Indian Subcontinent Regional Orchid Specialist Group covers the Indian subcontinental region. In the international scenario, several treaties have been formulated for the protection of biodiversity as a whole, which encompasses the protection of wild orchids also. The Convention of International Trade in Endangered Species of Wild Fauna and Flora (CITES), ratified by India, places all species of Orchidaceae under Appendix II, meaning thereby that their trade will be only through export permits.

Orchids are one such group of plants which grow in a variety of habitats throughout the globe, but they are very sensitive to habitat change. A number of species are rare and threatened throughout the world, including western Himalaya, owing to habitat degradation and fragmentation as a result of various anthropogenic influences such as land development activities, building of dams, constructions of roads, commercial exploitation of the species, overgrazing and frequent forest fires. Some orchid species require unique habitat and microhabitats so they are confined to particular elevations and forest types. Some are naturally rare; others are so because of geographic distribution, narrow habitat requirements, and lowdensity populations. Several species that have been reported earlier from the region have not been recollected, thus indicating their possible disappearance due to habitat changes. As most of the orchids are insect pollinated, the depletion in the population of insect pollinators may also lead to the depletion in the population of particular orchid species. The present 
study is an attempt to give an account of the present status of orchids based on recent surveys.

\section{Material and Methods}

Study area: The study was conducted in western Himalaya of India that lies between $28^{\circ} 45^{\prime}-36^{\circ} 20^{\prime} \mathrm{N} \&$ $73^{\circ} 26^{\prime}-80^{\circ} 24^{\prime} \mathrm{E}$ (Image 1). The landmass encompasses three states viz., Uttarakhand (UK), Himachal Pradesh (HP) and Jammu \& Kashmir (JK), occupies roughly $331,402 \mathrm{~km}^{2}$ area, which is approximately $10.08 \%$ of India's total geographic area. Altitude varies from 300-7800 m.

Data collection: Data was collected from three different sources: (i) Herbaria: The Botanical Survey of India, Northern Circle (BSD), Forest Research Institute (DD), Wildlife Institute of India (WII), Kumaun University Nainital (NTL), H.N.B Garhwal University, Srinagar (GUH) and Punjab University Herbarium (PAN) were visited and data on habitat, locality, altitude and flowering were gathered. Based on this information past localities from where the species were collected were also visited, to know the present status and changes in population-size.

(ii) Review of literature: Significant literature, namely, Collett (1902), Duthie (1906), Raizada et al. (1981), Vij et al. (1982, 1983), Chowdhery \& Wadhwa (1984), Deva \& Naithani (1986), Pangtey et al. (1991)

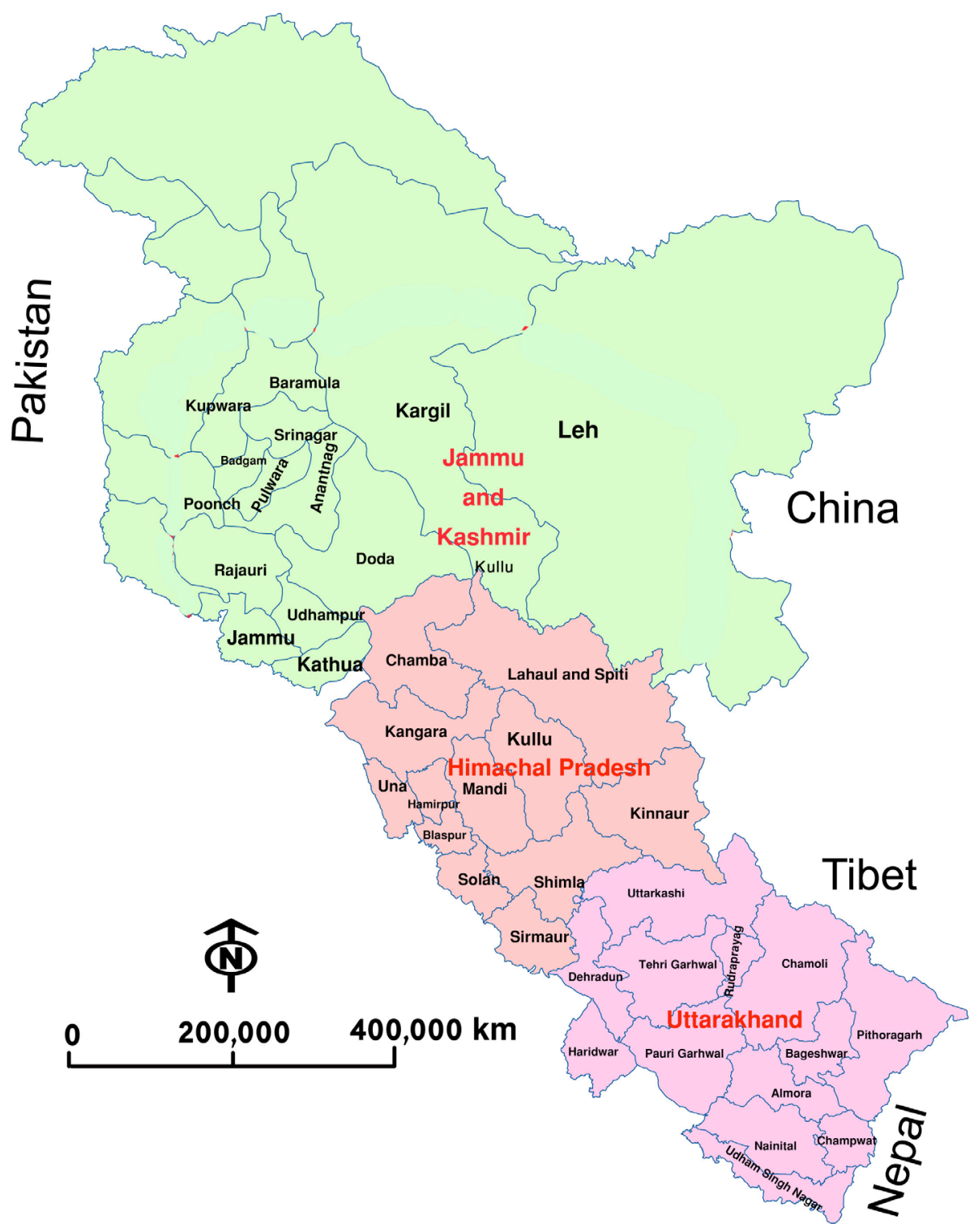

Image 1. Map of western Himalaya 
and various research papers published in national and international journals were used.

(iii) Field survey: Extensive field surveys conducted from 2002 to 2010 in different seasons and various localities covering altitudes from 300-4800 m. Various parameters such as habit, altitude, forest types and associate species were recorded. The elevation zone was divided into nine $500 \mathrm{~m}$ intervals between $300 \mathrm{~m}$ and $4800 \mathrm{~m}$ (the higher limit of the orchids in western Himalaya is $4800 \mathrm{~m}$ ), with the starting zone $<500 \mathrm{~m}$ and the final $>4000 \mathrm{~m}$. Eighteen habitat types were identified for orchids, based on species presence in each habitat.

No assessment has been done for the conservation status of orchids in the past for this region hence assigning IUCN categories is somewhat impractical here. In most of the cases, information is missing even when they were not collected for more than 100 years. These species were kept in doubtful categories and are not included in the analysis (Table 1).

Data analysis: A formula was developed for convenience to assign a status at local level to each species. Six quantification parameters were taken for assessing orchids (Table 2). For getting the rarity value $(\mathrm{R})$ (on the scale of rarity index; $1-5$ ), the sum of all six parameters were divided by six. The species with the least number were ranked rarer in comparison with those with greater values. All the data were entered in an Excel spreadsheet and summarized using descriptive statistics.

$$
\mathrm{R}=\frac{\mathrm{h}^{1}+\mathrm{s}^{1}+\mathrm{a}^{1}+w \mathrm{~h}^{1}+\mathrm{p}^{1}+\mathrm{p}^{2}}{6}
$$

where $\mathrm{h}^{1}$-number of habitats, $\mathrm{s}^{1}$-number of sites, $\mathrm{a}^{1}$ - altitudinal distribution, wh $\mathrm{h}^{1}$ - distribution in western Himalaya, $\mathrm{p}^{1}$ — phytogeographical distribution within the Indian subcontinent, $\mathrm{p}^{2}$ - phytogeographical distribution globally.

Rarity ranking (very rare: 1-2, sparse: 2.1-3, occasional: 3.1-4, common: 4.1-5).

\section{Results and Discussion}

Status of orchids: It is very difficult to make an accurate account of orchid species of western Himalaya, with its vast size, remoteness and varied topographic conditions. The study reveals that $40 \%$ (88) of orchid species are very rare, $26 \%$ are sparse, $19 \%$ are occasional and $15 \%$ are common in western
Table 1. List of doubtful species

\begin{tabular}{|c|c|}
\hline Sno & Species \\
\hline 1 & Anoectochilus roxburghii \\
\hline 2 & Aphyllorchis gollani \\
\hline 3 & Arundina graminifolia \\
\hline 4 & Calanthe alismifolia \\
\hline 5 & Calanthe brevicornu \\
\hline 6 & Chiloschista usneoides \\
\hline 7 & Coelogyne flaccida \\
\hline 8 & Coelogyne nitida \\
\hline 9 & Cymbidium eburneum \\
\hline 10 & Cymbidium longifolium \\
\hline 11 & Dendrobium moschatum \\
\hline 12 & Dendrobium transparens \\
\hline 13 & Diphylax urceolata \\
\hline 14 & Eulophia mackinnonii \\
\hline 15 & Eulophia obtusa \\
\hline 16 & Gastrochilus garhwalensis \\
\hline 17 & Geodorum densiflorum \\
\hline 18 & Habenaria longifolia \\
\hline 19 & Liparis cordifolia \\
\hline 20 & Liparis nervosa \\
\hline 21 & Oberonia iridifolia \\
\hline 22 & Spiranthes spiralis \\
\hline
\end{tabular}

Himalaya (Fig. 1; Appendix 1).

Threats to orchids: Orchids are a highly specialized group of plants and have modified themselves in such a way that they occur in almost every ecosystem. They have a peculiar habit of interdependence on mycorrhiza for germination and nutrition. Any imbalance in the habitat can cease the regeneration and growth of orchids. Thus, they are more vulnerable to the destruction of habitat. Orchids are usually threatened due to habitat loss, degradation and fragmentation. These can be caused by natural threats, anthropogenic pressures and threats posed by invasive species.

1. Natural threats: Due to the undulating topography and the varying geological set up of western Himalaya, several areas have been identified that are prone to landslides, floods etc., which affect the natural population of many terrestrial and epiphytic orchids leading to their extinction. Many host trees growing along the river banks at lower and mid altitudes are swept away by floods, thus removing several orchids. In many areas, landsides were seen to carry away the 
Table 2. Quantification parameters of rarity for each orchid species

\begin{tabular}{|c|c|c|c|}
\hline Sno & Parameters & Documentation & Scoring (Quantification) \\
\hline 1 & Number of Habitats $\left(h^{1}\right)$ & $\begin{array}{l}\text { Number of habitats in which each orchid species } \\
\text { were found was recorded. }\end{array}$ & $\begin{array}{l}1 \text { to } 18 \text { habitats depending on how many habitats, } \\
\text { a particular orchid occurred in. }\end{array}$ \\
\hline 2 & Number of Sites $\left(\mathrm{s}^{1}\right)$ & $\begin{array}{l}\text { Number of sites in which each orchid was found } \\
\text { was recorded. }\end{array}$ & $\begin{array}{l}\text { "1" for single site; } \\
\text { " } 2 \text { " for }<5 \text { sites; } \\
\text { " } 3 \text { " for }<10 \text { sites; } \\
\text { " } 4 \text { "for }<15 \text { sites and } \\
\text { " for }>15 \text { sites. }\end{array}$ \\
\hline 3 & Altitudinal distribution $\left(\mathrm{a}^{1}\right)$ & $\begin{array}{l}<500 \mathrm{~m} \text { to }>4000 \mathrm{~m} \text { (total } 9 \text { zones) depending on } \\
\text { how many species occurred in a particular zone. }\end{array}$ & $\begin{array}{l}1 \text { to } 9 \text { zones depending on how many zones a } \\
\text { particular species was found in. }\end{array}$ \\
\hline 4 & $\begin{array}{l}\text { Distribution in western } \\
\text { Himalaya }\left(w^{1}\right)\end{array}$ & $\begin{array}{l}\text { Divided in to } 4 \text { divisions } \\
\text { 1. Srinagar valley, Leh, Kargil and Lahul \& Spiti } \\
\text { 2. Jammu and its adjoining districts and } \\
\text { Himachal Pradesh (except Lahul \& Spiti) } \\
\text { 3. Garhwal division } \\
\text { 4. Kumaun Division }\end{array}$ & $\begin{array}{l}1 \text { to } 4 \text { divisions depending on the occurrence of } \\
\text { species in a particular division. }\end{array}$ \\
\hline 5 & $\begin{array}{l}\text { Phytogeographical } \\
\text { Distribution }\left(\mathrm{p}^{1}\right)\end{array}$ & $\begin{array}{l}\text { Indian sub-continents (Pakistan, Nepal, Bhutan, } \\
\text { northeastern states, Sri Lanka, Bangladesh) }\end{array}$ & $\begin{array}{l}\text { Depending on how many species are spread in a } \\
\text { particular region. }\end{array}$ \\
\hline 6 & $\begin{array}{l}\text { Phytogeographical } \\
\text { Distribution }\left(\mathrm{p}^{2}\right)\end{array}$ & $\begin{array}{l}\text { Europe, Sino-Japan, China, Indo-Malaya, Africa, } \\
\text { Australia, North and South America }\end{array}$ & $\begin{array}{l}\text { Depending on how many species are spread in a } \\
\text { particular region. }\end{array}$ \\
\hline
\end{tabular}

hill-slopes with them during the rainy season. The terrestrial orchids carried down by landslides are dumped into soil, thus destroyed. The global climatic variation brings a lot of variation in the local climate. The local rainfall patterns are changing and most of the terrestrial orchids are affected by this change. They show active growth at the beginning of rainfall. If the rain is delayed, it hampers the life cycle of most of the rain dependent orchids like Nervilia spp. Most of the orchids are pollinated by insects, which may be specific for orchids. Lack of pollinators in nature can affect the survival of orchids.

\section{Anthropogenic threats:}

Habitat fragmentation: Habitat destruction is identified as the main threat to orchid diversity. It is

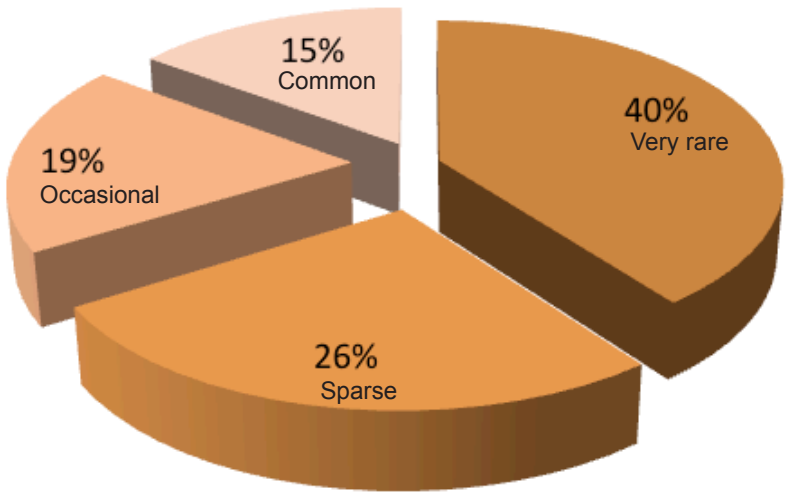

Figure 1. Status representations of orchids $(n=221$ species) often a cause of species becoming threatened. The main habitats for orchids are sal forests, riverine forests and oak forests in western Himalaya. Increasing demands of the local people and their dependency on the forests are identified as the main threats to the orchid habitats. Both terrestrial and epiphytic orchids are affected by habitat fragmentation. Many orchids, especially mycoheterotrophic orchids require dense forest cover. Little canopy exposure can wipe out the population. Epiphytic orchids are mainly inhabitants of the riverine forests. These forests provide a suitable climate and humidity for the growth of epiphytic orchids.

Deforestation activities coupled with the lopping of host plants for fodder, fuel and timber causes the riverine forests to change rapidly. Lopping and cutting of the host trees for fodder and fuel are a regular phenomenon in the hills. Therefore, the occurrence and growth of most of the epiphytic orchids are adversely affected. Epiphytic orchids growing on fodder trees have been removed due to the excessive and unscientific ways of lopping. In western Himalaya, oak forests are predominant. Among the oaks, Quercus leucotrichophora has been identified as an excellent tree host particularly in many epiphytic orchid dominated areas and it supports fairly large numbers of orchid species. But this tree is a good source of fodder and fuel too. Branches along with leaves are lopped to a great extent making the trees almost naked. Therefore lopping of banj-oak and other fodder species that support a high number of 
epiphytic orchids have reduced the abundance of these epiphytic orchids.

Developmental activities: New roads, dams, mines, buildings and other developments strongly contribute to habitat loss in this region, not only directly by damaging forests but also indirectly by displacing them. A typical example is the Snow Orchid Diplomeris hirsuta which was reported from Dogaon near Nainital and this was the only locality in western Himalaya where it was found at the time. This locality is very close to the National Highway 87. Naturally, this species is confined to fragile sand stone rocks in the foothills of the area. In 1996, the state government took a decision to widen National Highway 87, the rocks where the species were growing were destroyed and the only remaining population of the species vanished from the area. Recent surveys show only a small remaining population ca. 110 individuals of this species growing in a nearby locality. Another example of developmental activities is Tehri Dam (Uttarakhand). It is one of the largest dams in Asia with a submerge area of $44 \mathrm{~km}^{2}$. This submerge stretch was entirely covered by many small patches of riverine forests which were an ideal habitat for many epiphytic orchids.

Over exploitation: Although very few orchid species are medicinally important in the study area, over exploitation of these species coupled with a lack of awareness, has resulted in their becoming very rare and endangered in natural population and they are bound to become extinct in the near future. Terrestrial orchids such as Crepidium acuminatum, Malaxis muscifera, Platanthera edgworthii, Eulophia dabia and Dactylorhiza hatagirea are used in the preparation of various medicines by pharmaceutical companies. They have been subjected to ruthless collection from their natural habitats.

Overgrazing: The high altitude grasslands, pastures and meadows are very important habitats for many alpine orchids. These habitats are facing threats due to overgrazing practices by many pastoral communities. The foothills of the study area are inhabited by small groups of nomadic pastoral communities such as Gujjars in Siwalik zone, Himachal Pradesh and Jammu, and Bokshas and Tharus in the eastern Tarai zone. They are forest dwelling, semi-nomadic and pastoral indigenous communities. They own large herds of cattle and use forest land for grazing. The cattle were often found to be eating not only young flowering buds but also whole orchid plants.

Forest fires: Forest fires are another cause of the destruction of orchid host trees and of the thick layer of humus as well as of the pollinators. The forest is often set on fire by the local communities during the summer season to get a good growth of grass following the rains. Sometimes it spreads and destroys vast tracts of valuable forests. During the study, many orchid rich localities were found to be affected by fire. For epiphytic orchids, fires at any time of the year can cause a drastic change in plant abundance. They are mainly affected by burning of plants, degrading or removal of the support substrate and alteration of the microclimate resulting from fragmentation of the canopy. In many places, which were affected by previous fires, this phenomenon was observed, but this has hardly affected the terrestrial orchids such as Nervilia spp., which were seen in good abundance.

\section{Threats by invasive species:}

It was observed during the study that some invasive species were suppressing the growth of native flora including orchids, in many important orchid habitats. A large tract of the foothills and upper Himalayan range up to $2500 \mathrm{~m}$ has been largely encroached by invasive species such as Eupatorium adenophorum, Eupatorium odoratum, Eupatorium riparium, Lantana camara, Parthenium hysterophorus and Ageratum conyzoides. Their multifaceted adaptability and fast replicating characteristics have created a serious threat to the indigenous flora including orchids. Several terrestrial orchid species were found to be shockingly less in number in such habitats. Orchids that face threats by these alien species are Eulophia spp., Liparis deflexa, Nervilia spp., Goodyera procera, Habenaria marginata, H. plantaginea, H. pubescens, Pachystoma pubescens, Peristylus constrictus, P. goodyeroides, P. lawii etc. Various dead host species were seen heavily loaded with epiphytic orchids in the study area particularly in riverine belts. After death, the bark of the tree gets loose and as the epiphytic orchids attach themselves mainly on the surface of the bark, these epiphytic orchids often fall to the ground due to their own weight and die. 


\section{Strategies for conservation}

Conservation is "the maintenance of essential ecological processes and life-support systems, the preservation of genetic diversity and the sustainable utilization of species and ecosystems" (Talbot 1980). Orchids are an endangered plant group and protected by national or local laws in many countries including India. International trade and collection of orchids from the wild is banned. The wide range of distribution and habitats of orchids makes it difficult to have a uniform code for conservation. The western Himalaya is such a vast landscape spread over a $331,402 \mathrm{~km}^{2}$ area and the distribution of orchids is very patchy so it is very difficult to conserve each and every forest patch. The question is: 'Which area should be selected for orchid conservation?' the answer has to be given after a thorough evaluation of many aspects.

\section{Identifying Orchid Conservation Areas (OCAs)}

In order to conserve the orchids, it was necessary to identify orchid conservation areas (OCA). Various parameters were used to select a conservation area. First a region wise orchid Index was calculated (Table 3). That was calculated as the ratio of the number of orchids in a particular region multiplied by 1000 (IUCN 1996). This helped to get a broad region for selection. After getting the orchid index value the focus moved to the region that indicated the maximum value. Kumaun region showed the maximum value at 9.69 followed by Garhwal region at 5.33. Based on past and present records, two areas were found to be suitable for OCAs. One is Gori Valley in eastern Kumaun and the other is Mandal Valley in Chamoli District of Garhwal.

\section{Suggestive measures for conservation}

As mentioned above, all the orchids are threatened in the study area. For their long term survival in nature, they need to be protected through in situ and ex situ conservation. In situ orchid conservation and habitat preservation is the first line of defense for safeguarding orchid species for the future. The following measures are suggested for the long term conservation of orchids in western Himalaya:

(i) 145 species, which are very rare and sparse in the study area, need immediate action for conservation.

(ii) Banj-oak forests and riverine forests should be
Table 3. Orchid Index table

\begin{tabular}{|c|l|c|c|c|}
\hline Sno & Geographical region & $\begin{array}{c}\text { Area } \\
\mathbf{( k m}^{\mathbf{2}}\end{array}$ & $\begin{array}{c}\text { Total } \\
\text { Species }\end{array}$ & $\begin{array}{c}\text { Orchid } \\
\text { Index }\end{array}$ \\
\hline $\mathbf{1}$ & Jammu \& Kashmir & 222,236 & 46 & 0.21 \\
\hline $\mathbf{2}$ & Himachal Pradesh & 55,673 & 76 & 1.36 \\
\hline $\mathbf{3}$ & Garhwal region & 32,448 & 173 & 5.33 \\
\hline $\mathbf{4}$ & Kumaun Region & 21,035 & 204 & 9.69 \\
\hline
\end{tabular}

protected region wise. Initiate ecological restoration of degraded riverine forests and promote afforestation of suitable host tree species such as Toona ciliata, Engelhadrtia spicata and Quercus leucotrichophora.

(iii) Endemic and near endemic species need special attention. For example, Peristylus kumaonensis is an endemic orchid reported by Dr. J. Renz in 1983 from a locality that is $5 \mathrm{~km}$ from Nainital towards the north, on the way to Ratighat at an altitude of $1800 \mathrm{~m}$ and it is restricted to this area alone. At that time, almost 130 individuals were counted in this particular locality (Y.P.S. Pangtey pers. comm. August 2004). During the current survey a drastic change in the whole area was observed due to anthropogenic pressures and the population now remains around 30 individuals only.

(iv) Urgent need to conduct a population monitoring program together with orchid ecology so that we can use this information to design orchid conservation plans for the intact regions of habitat where orchids still thrive.

(v) Establishment of orchid seed bank and germ plasm banks. The conservation of seeds is the most effective means of genetic conservation.

(vi) Local people should be made aware of this wealth by means of awareness programs. Orchid conservation areas can be developed for tourists and college students so that they can visit these areas during their educational trips.

\section{REFERENCES}

Chowdhery, H.J. \& B.M. Wadhwa (1984). Flora of Himachal Pradesh. Vol. 3. Botanical Survey of India, Calcutta, 680 860pp.

Collett, H. (1902). Flora of Simlensis. Thacker, Spink and Co., Simla, xvii+652.

Deva, S. \& H.B. Naithani (1986). The Orchid Flora of NorthWest Himalaya. Print and Media Associates, New Delhi, 459pp. 
Duthie, J.F. (1906). The Orchids of the North-Western Himalaya. Annals of the Royal Botanical Garden, Calcutta, 9(2): 81-211.

IUCN/SSC Orchid Specialist Group (1996). Orchids Status Survey and Conservation Action Plan. IUCN, Gland Switzerland and Cambridge, UK, vi+153pp. (Vol 1: xiii+367pp. Vol 2: 268pp. Vol 3: 271pp).

Pangtey, Y.P.S., S.S. Samant \& G.S. Rawat (1991). Orchids of Kumaon Himalaya. Bishan Singh Mahendra Pal Singh, Dehradun, 193pp.

Pradhan, G.M.(1975). Habitat destruction of Himalayan orchid jungles, pp. 193-198. In: Senghas, K. (ed.). Proceedings of Eigth World Orchid Conference. German Orchid Society, Frankfurt, 555pp.

Pradhan, U.C. (1971). Orchid conservation attempts in Sikkim and E. India. American Orchid Society Bulletin 40: 4.

Pradhan, U.C. (1975a). Conservation of Eastern Himalayan orchids: problems and prospects, pp. 335-340. In: Senghas, K. (ed.). Proceedings of Eigth World Orchid Conference. German Orchid Society, Frankfurt, 555pp.
Pradhan, U.C. (1975b). The Himalayan Cypripediums, pp. 199-204. In: Senghas, K. (ed.) Proceedings of Eigth World Orchid Conference. German Orchid Society, Frankfurt, $555 \mathrm{pp}$.

Pradhan, U.C. (1976). Indian Orchids. Guide to Identification and Culture I. Bharat Lithographing Co., 188pp.

Raizada, M.B., H.B. Naithani \& H.O. Saxena (1981). Orchids of Mussoorie. Bishan Singh Mahendra Pal Singh, Dehradun, 100pp.

Talbot, L.M. (1980). The World's Conservation Strategy. Environmental Conservation 7: 259-268.

Vij, S.P., I.S. Toor \& N. Skekhar (1982). Observations on orchidaceous flora of Simla and adjacent hills in the NW Himalayas (ecology and distribution). Research Bulletin of Panjab University 33(3\&4): 163-175.

Vij, S.P., N. Shekhar, S.K. Kashyap \& A.K. Garg (1983). Observations on the orchids of Nainital and adjacent hills in the Central Himalaya (Ecology and Distribution). Research Bulletin. Panjab University 34(3): 63-76.

Appendix I. List of orchids and their status

\begin{tabular}{|c|c|c|c|}
\hline & Species & Habit & Status \\
\hline 1 & Acampe carinata & $\mathrm{E}$ & C \\
\hline 2 & Acampe rigida & $\mathrm{E}$ & SP \\
\hline 3 & Aerides multiflora & $\mathrm{E}$ & C \\
\hline 4 & Aerides odorata & E & C \\
\hline 5 & Androcorys josephi & $\mathrm{T}$ & SP \\
\hline 6 & Androcorys monophylla & $\mathrm{T}$ & 0 \\
\hline 7 & Androcorys pugioniformis & $\mathrm{T}$ & SP \\
\hline 8 & Ascocentrum ampullaceum & E & VR \\
\hline 9 & Brachycorythis obcordata & $\mathrm{T}$ & C \\
\hline 10 & Bulbophyllum affine & $\mathrm{E}$ & 0 \\
\hline 11 & Bulbophyllum careyanum & E & SP \\
\hline 12 & Bulbophyllum cariniflorum & E & O \\
\hline 13 & Bulbophyllum helenae & E & VR \\
\hline 14 & Bulbophyllum hirtum & E & VR \\
\hline 15 & Bulbophyllum hookeri & E & VR \\
\hline 16 & Bulbophyllum leopardinum & E & VR \\
\hline 17 & Bulbophyllum polyrhizum & E & SP \\
\hline 18 & Bulbophyllum reptans & E & O \\
\hline 19 & Bulbophyllum triste & E & $\mathrm{O}$ \\
\hline 20 & Bulbophyllum umbellatum & E & 0 \\
\hline 21 & Bulbophyllum wallichii & $\mathrm{E}$ & VR \\
\hline 22 & Calanthe alpina & $\mathrm{T}$ & VR \\
\hline 23 & Calanthe mannii & $\mathrm{T}$ & VR \\
\hline 24 & Calanthe pachystalix & $\mathrm{T}$ & VR \\
\hline 25 & Calanthe plantaginea & $\mathrm{T}$ & SP \\
\hline 26 & Calanthe puberula & T & SP \\
\hline
\end{tabular}

\begin{tabular}{|c|c|c|c|}
\hline & Species & Habit & Status \\
\hline 27 & Calanthe tricarinata & $\mathrm{T}$ & C \\
\hline 28 & Cephalanthera Iongifolia & $\mathrm{T}$ & C \\
\hline 29 & Cheirostylis griffithii & $\mathrm{T}$ & SP \\
\hline 30 & Cleisostoma aspersum & $\mathrm{E}$ & VR \\
\hline 31 & Coeloglossum viride & $\mathrm{T}$ & SP \\
\hline 32 & Coelogyne cristata & $\mathrm{E}$ & C \\
\hline 33 & Coelogyne ovalis & $\mathrm{E}$ & 0 \\
\hline 34 & Coelogyne stricta & $\mathrm{E}$ & SP \\
\hline 35 & Corallorhiza trifida & $\mathrm{H}$ & VR \\
\hline 36 & Crepidium acuminatum & $\mathrm{T}$ & C \\
\hline 37 & Crepidium biauritum & $\mathrm{T}$ & VR \\
\hline 38 & Crepidium mackinnonii & $\mathrm{T}$ & VR \\
\hline 39 & Crepidium purpureum & $\mathrm{T}$ & 0 \\
\hline 40 & Cryptochilus luteus & $\mathrm{E}$ & VR \\
\hline 41 & Cymbidium aloifolium & $\mathrm{E}$ & SP \\
\hline 42 & Cymbidium cyperifolium & E & SP \\
\hline 43 & Cymbidium hookerinum & $\mathrm{E}$ & SP \\
\hline 44 & Cymbidium iridoides & $\mathrm{E}$ & 0 \\
\hline 45 & Cymbidium macrorhizon & $\mathrm{H}$ & SP \\
\hline 46 & Cypripedium cordigerum & $\mathrm{T}$ & SP \\
\hline 47 & Cypripedium elegans & $\mathrm{T}$ & VR \\
\hline 48 & Cypripedium himalaicum & $\mathrm{T}$ & VR \\
\hline 49 & Dactylorhiza hatagirea & $\mathrm{T}$ & 0 \\
\hline 50 & Dactylorhiza kafiriana & $\mathrm{T}$ & VR \\
\hline 51 & Dendrobium amoenum & $\mathrm{E}$ & 0 \\
\hline 52 & Dendrobium aphyllum & $\mathrm{E}$ & SP \\
\hline
\end{tabular}




\begin{tabular}{|c|c|c|c|c|c|c|c|}
\hline & Species & Habit & Status & & Species & Habit & Status \\
\hline 53 & Dendrobium bicameratum & $E$ & $\mathrm{C}$ & 99 & Goodyera fusca & $\mathrm{T}$ & SP \\
\hline 54 & Dendrobium candidum & $E$ & SP & 100 & Goodyera procera & $\mathrm{T}$ & $\mathrm{O}$ \\
\hline 55 & Dendrobium chrysanthum & $E$ & SP & 101 & Goodyera repens & $\mathrm{T}$ & $\mathrm{C}$ \\
\hline 56 & Dendrobium chryseum & $E$ & $\mathrm{O}$ & 102 & Goodyera viridiflora & $\mathrm{T}$ & $\mathrm{O}$ \\
\hline 57 & Dendrobium crepidatum & $E$ & SP & 103 & Goodyera vittata & $\mathrm{T}$ & VR \\
\hline 58 & Dendrobium denudans & $E$ & SP & 104 & Gymnadenia orchidis & $\mathrm{T}$ & SP \\
\hline 59 & Dendrobium fimbriatum & $\mathrm{E}$ & VR & 105 & Habenaria aitchisonii & $\mathrm{T}$ & $\mathrm{O}$ \\
\hline 60 & Dendrobium fugax & $E$ & SP & 106 & Habenaria arietina & $\mathrm{T}$ & SP \\
\hline 61 & Dendrobium hesperis & $E$ & VR & 107 & Habenaria commelinifolia & $\mathrm{T}$ & VR \\
\hline 62 & Dendrobium heterocarpum & $E$ & VR & 108 & Habenaria digitata & $\mathrm{T}$ & SP \\
\hline 63 & Dendrobium monticola & $E$ & SP & 109 & Habenaria diphylla & $\mathrm{T}$ & SP \\
\hline 64 & Dendrobium primulinum & $\mathrm{E}$ & $\mathrm{O}$ & 110 & Habenaria ensifolia & $\mathrm{T}$ & SP \\
\hline 65 & Didiciea cunninghamii & $\mathrm{T}$ & VR & 111 & Habenaria furcifera & $\mathrm{T}$ & SP \\
\hline 66 & Diphylax griffithii & $\mathrm{T}$ & SP & 112 & Habenaria intermedia & $\mathrm{T}$ & C \\
\hline 67 & Diplomeris hirsuta & $\mathrm{T}$ & VR & 113 & Habenaria marginata & $\mathrm{T}$ & $\mathrm{O}$ \\
\hline 68 & Epipactis gigantea & $\mathrm{T}$ & VR & 114 & Habenaria pectinata & $\mathrm{T}$ & $\mathrm{C}$ \\
\hline 69 & Epipactis helleborine & $\mathrm{T}$ & $\mathrm{C}$ & 115 & Habenaria plantaginea & $\mathrm{T}$ & $\mathrm{O}$ \\
\hline 70 & Epipactis veratrifolia & $\mathrm{T}$ & $\mathrm{O}$ & 116 & Habenaria pubescens & $\mathrm{T}$ & VR \\
\hline 71 & Epipogium aphyllum & $\mathrm{H}$ & VR & 117 & Habenaria stenopetala & $\mathrm{T}$ & SP \\
\hline 72 & Epipogium roseum & $\mathrm{H}$ & VR & 118 & Hemipilia cordifolia & $\mathrm{T}$ & $\mathrm{O}$ \\
\hline 73 & Eria alba & $E$ & $\mathrm{O}$ & 119 & Herminium kumaunensis & $\mathrm{T}$ & VR \\
\hline 74 & Eria amica & $E$ & VR & 120 & Herminium lanceum & $\mathrm{T}$ & $\mathrm{C}$ \\
\hline 75 & Eria bipunctata & $E$ & $\mathrm{O}$ & 121 & Herminium mackinnonii & $\mathrm{T}$ & VR \\
\hline 76 & Eria coronaria & $E$ & VR & 122 & Herminium monorchis & $\mathrm{T}$ & SP \\
\hline 77 & Eria globulifera & $E$ & VR & 123 & lone bicolor & $E$ & $\mathrm{SP}$ \\
\hline 78 & Eria graminifolia & $E$ & VR & 124 & Liparis caespitosa & $E$ & SP \\
\hline 79 & Eria lasiopetala & $E$ & $\mathrm{O}$ & 125 & Liparis deflexa & $\mathrm{T}$ & VR \\
\hline 80 & Eria muscicola & $E$ & VR & 126 & Liparis glossula & $\mathrm{T}$ & O \\
\hline 81 & Eria occidentalis & $E$ & VR & 127 & Liparis paradoxa & $\mathrm{T}$ & SP \\
\hline 82 & Eria reticosa & $E$ & VR & 128 & Liparis platyrachis & $\mathrm{E}$ & VR \\
\hline 83 & Eria spicata & $E$ & $\mathrm{O}$ & 129 & Liparis resupinata & $\mathrm{T}$ & VR \\
\hline 84 & Eulophia bicallosa & $\mathrm{T}$ & VR & 130 & Liparis rostrata & $\mathrm{T}$ & C \\
\hline 85 & Eulophia dabia & $\mathrm{T}$ & $\mathrm{SP}$ & 131 & Liparis viridiflora & $\mathrm{T}$ & $\mathrm{O}$ \\
\hline 86 & Eulophia explanata & $\mathrm{T}$ & VR & 132 & Luisia brachystachys & $E$ & VR \\
\hline 87 & Eulophia flava & $\mathrm{T}$ & VR & 133 & Luisia trichorrhiza & $E$ & 0 \\
\hline 88 & Eulophia graminea & $\mathrm{T}$ & VR & 134 & Luisia tristis & $E$ & $\mathrm{C}$ \\
\hline 89 & Eulophia herbacea & $\mathrm{T}$ & VR & 135 & Luisiopsis inconspicuua & $E$ & SP \\
\hline 90 & Galearis roborovskyi & $\mathrm{T}$ & VR & 136 & Malaxis cylindrostachya & $\mathrm{T}$ & $\mathrm{O}$ \\
\hline 91 & Galearis spathulata & $T$ & SP & 137 & Malaxis latifolia & $\mathrm{T}$ & VR \\
\hline 92 & Galeola falconeri & $\mathrm{H}$ & VR & 138 & Malaxis muscifera & $\mathrm{T}$ & $\mathrm{C}$ \\
\hline 93 & Gastrochilus acutifolius & $\mathrm{E}$ & VR & 139 & Neottia acuminata & $\mathrm{H}$ & VR \\
\hline 94 & Gastrochilus calceolaris & $E$ & C & 140 & Neottia inayatii & $\mathrm{H}$ & VR \\
\hline 95 & Gastrochilus distichus & $E$ & $\mathrm{SP}$ & 141 & Neottia listeroides & $\mathrm{H}$ & $\mathrm{O}$ \\
\hline 96 & Gastrodia falconeri & $\mathrm{H}$ & VR & 142 & Neottia longicaulis & $\mathrm{T}$ & VR \\
\hline 97 & Goodyera biflora & $\mathrm{T}$ & $\mathrm{O}$ & 143 & Neottia mackinnonii & $\mathrm{H}$ & VR \\
\hline 98 & Goodyera foliosa & $\mathrm{T}$ & VR & 144 & Neottia microglottis & $\mathrm{H}$ & VR \\
\hline
\end{tabular}




\begin{tabular}{|c|c|c|c|}
\hline & Species & Habit & Status \\
\hline 145 & Neottia nandadeviensis & $\mathrm{T}$ & VR \\
\hline 146 & Neottia ovata & $\mathrm{T}$ & VR \\
\hline 147 & Neottia pinetorum & $\mathrm{T}$ & VR \\
\hline 148 & Neottia tenuis & $\mathrm{T}$ & SP \\
\hline 149 & Neottianthe calcicola & $\mathrm{T}$ & VR \\
\hline 150 & Neottianthe secundiflora & $\mathrm{T}$ & VR \\
\hline 151 & Nervilia aragoana & $\mathrm{T}$ & $\mathrm{O}$ \\
\hline 152 & Nervilia crociformis & $\mathrm{T}$ & C \\
\hline 153 & Nervilia falcata & $\mathrm{T}$ & VR \\
\hline 154 & Nervilia gammieana & $\mathrm{T}$ & $\mathrm{O}$ \\
\hline 155 & Nervilia gleadowii & $\mathrm{T}$ & VR \\
\hline 156 & Nervilia infundibulifolia & $\mathrm{T}$ & VR \\
\hline 157 & Nervilia mackinnonii & $\mathrm{T}$ & $\mathrm{O}$ \\
\hline 158 & Nervilia pangteyiana & $\mathrm{T}$ & VR \\
\hline 159 & Nervilia plicata & $\mathrm{T}$ & SP \\
\hline 160 & Oberonia acaulis & $E$ & SP \\
\hline 161 & Oberonia caulescens & $\mathrm{E}$ & VR \\
\hline 162 & Oberonia ensiformis & $E$ & SP \\
\hline 163 & Oberonia falconeri & $E$ & $\mathrm{O}$ \\
\hline 164 & Oberonia griffithiana & $\mathrm{E}$ & VR \\
\hline 165 & Oberonia myosurus & $E$ & VR \\
\hline 166 & Oberonia pachyrachis & $\mathrm{E}$ & $\mathrm{O}$ \\
\hline 167 & Oberonia prainiana & $E$ & VR \\
\hline 168 & Oberonia pyrulifera & $\mathrm{E}$ & SP \\
\hline 169 & Oreorchis foliosa & $\mathrm{T}$ & SP \\
\hline 170 & Oreorchis foliosa var. indica & $\mathrm{T}$ & SP \\
\hline 171 & Oreorchis micrantha & $\mathrm{T}$ & $\mathrm{O}$ \\
\hline 172 & Ornithochilus difformis & $\mathrm{E}$ & $\mathrm{O}$ \\
\hline 173 & Otochilus lancilabius & $E$ & VR \\
\hline 174 & Pachystoma pubescens & $\mathrm{T}$ & SP \\
\hline 175 & Pecteilis gigantea & $\mathrm{T}$ & SP \\
\hline 176 & Pecteilis triflora & $\mathrm{E}$ & VR \\
\hline 177 & Pelatantheria insectifera & $\mathrm{E}$ & VR \\
\hline 178 & Peristylus affinis & $\mathrm{T}$ & SP \\
\hline 179 & Peristylus constrictus & $\mathrm{T}$ & C \\
\hline 180 & Peristylus duthiei & $\mathrm{T}$ & $\mathrm{SP}$ \\
\hline 181 & Peristylus elisabethae & $\mathrm{T}$ & C \\
\hline 182 & Peristylus fallax & $\mathrm{T}$ & C \\
\hline 183 & Peristylus goodyeroides & $\mathrm{T}$ & $\mathrm{O}$ \\
\hline
\end{tabular}

\begin{tabular}{|c|c|c|c|}
\hline & Species & Habit & Status \\
\hline 184 & Peristylus kumaonensis & $\mathrm{T}$ & VR \\
\hline 185 & Peristylus lawii & $\mathrm{T}$ & VR \\
\hline 186 & Phaius tankervilleae & $\mathrm{T}$ & SP \\
\hline 187 & Phalaenopsis deliciosa & $E$ & VR \\
\hline 188 & Phalaenopsis taenialis & $E$ & SP \\
\hline 189 & Pholidata articulata & $E$ & $\mathrm{C}$ \\
\hline 190 & Pholidata imbricata & $E$ & $\mathrm{C}$ \\
\hline 191 & Platanthera arcuata & $\mathrm{T}$ & VR \\
\hline 192 & Platanthera clavigera & $\mathrm{T}$ & C \\
\hline 193 & Platanthera edgworthii & $\mathrm{T}$ & $\mathrm{C}$ \\
\hline 194 & Platanthera latilabris & $\mathrm{T}$ & C \\
\hline 195 & Platanthera leptocaulon & $\mathrm{T}$ & SP \\
\hline 196 & Platanthera stenantha & $\mathrm{T}$ & SP \\
\hline 197 & Pleione grandiflora & $E$ & VR \\
\hline 198 & Pleione hookeriana & $E$ & SP \\
\hline 199 & Pleione humilis & $E$ & VR \\
\hline 200 & Pleione praecox & $E$ & VR \\
\hline 201 & Ponerorchis chusua & $\mathrm{T}$ & $\mathrm{O}$ \\
\hline 202 & Ponerorchis renzii & $\mathrm{T}$ & VR \\
\hline 203 & Pteroceras teres & $E$ & SP \\
\hline 204 & Rhynchostylis retusa & $E$ & $\mathrm{C}$ \\
\hline 205 & Satyrium nepalense & $\mathrm{T}$ & $\mathrm{C}$ \\
\hline 206 & Satyrium nepalense var. ciliatum & $\mathrm{T}$ & VR \\
\hline 207 & Smithandia micrantha & $\mathrm{E}$ & $\mathrm{C}$ \\
\hline 208 & Spiranthes sinensis & $\mathrm{T}$ & C \\
\hline 209 & Thelasis longifolia & $E$ & VR \\
\hline 210 & Thunia alba & $E$ & C \\
\hline 211 & Thunia alba var. bracteata & $E$ & SP \\
\hline 212 & Tropidia pedunculata & $\mathrm{T}$ & VR \\
\hline 213 & Vanda alpina & $E$ & VR \\
\hline 214 & Vanda cristata & $E$ & $\mathrm{C}$ \\
\hline 215 & Vanda pumila & $E$ & VR \\
\hline 216 & Vanda tessellata & $E$ & $\mathrm{O}$ \\
\hline 217 & Vanda testacea & $E$ & $\mathrm{O}$ \\
\hline 218 & Vandopsis undulata & $E$ & VR \\
\hline 219 & Zeuxine flava & $\mathrm{T}$ & SP \\
\hline 220 & Zeuxine grandis & $\mathrm{T}$ & VR \\
\hline 221 & Zeuxine strateumatica & $\mathrm{T}$ & $\mathrm{O}$ \\
\hline
\end{tabular}

T - Terrestrial; E - Epiphytic; H - Holomycotrophic; VR - Very rare; SP - Sparse; O - Occasional; C - Common 